\title{
How Does the Rohingya Influx Influence the Residential Satisfaction and Mobility Intentions of the Host Communities in Bangladesh?
}

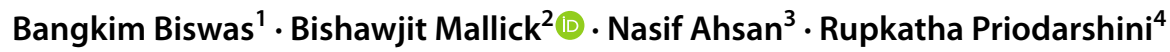

Accepted: 24 August 2021 / Published online: 10 September 2021

(c) The Author(s) 2021

\begin{abstract}
This study investigates the residential satisfaction and future relocation intention of the host communities neighbouring Rohingya migrants in Bangladesh. An empirical study of 151 households was conducted in Ukhiya and Ramu Upazila of Cox's Bazar district in late 2019. The residential satisfaction component includes the social environment (SE), neighbourhood environment (NE), and public services and facilities (PS\&F). It shows that, due to the Rohingya influx, the residential satisfaction level of the Ukhiya host communities declined by $30.17 \%$. Besides, to determine factors that impact on the intention to migrate, the ordinal logistic regression model has been run. A larger distance between the household and the Rohingya camps, longer duration of residence in the community, and a higher number of children in the family negatively influence the mobility intention of the host communities. Furthermore, the Hindu residents in the host communities have higher propensity to relocate. These findings demand that policies and programmes should be planned in a way that enables the host communities to stay in place despite the Rohingya influx.
\end{abstract}

Keywords Residential satisfaction - Intention to relocation - Influx of Rohingya • Host communities · Bangladesh

\section{Introduction}

Since August 2017, a large number of refugees, estimated to be around 745,000, have fled from Myanmar due to violence and entered Cox's Bazar and the Chittagong Hill Tracts in Bangladesh (UNDP, 2017). This dramatic population increase has placed stress on the local services, economy, and infrastructure (ISCG, 2018a, 2018b). According to ISCG (2018a, 2018b), firewood and transportation prices, water, essential services, food security, market access, economic vulnerability,

Bishawjit Mallick

bishawjit.mallick@tu-dresden.de

Extended author information available on the last page of the article 
environment, and job competition have all been affected due to this influx. Likewise, UNDP (2017) has reported that the arrival of Rohingya migrants has exerted enormous pressure on the local livelihoods, ecosystem, and the basic services of the host communities. The price of basic staples in the affected communities has risen and the wage of day labour has fallen (UNDP 2017). As Humanitarian Exchange (2018) reported, the influx of Rohingya has negatively impacted on Bangladeshi host communities in various ways; for instance, occupying the agricultural fields, which had been the primary income source of the poor; causing food prices to rise; and threatening the competitiveness of local labourers. Riley et al. (2017) have also found that massive environmental degradation has resulted from the Rohingya influx in the camp area, as well as concerns regarding security and safety. The education system has likewise been impacted, as students and teachers alike are employed to work for the refugee response (ISCG, 2018a, 2018b). To establish the Rohingya camps, over 2000 hectares of forest and cropland have been exhausted and about 700 tons a day of forest is disappearing due to firewood collection (ISCG, 2018a, 2018b).

The multifarious effects of the Rohingya influx mentioned above likely impact the host communities' residential satisfaction of the host communities, which in turn may influence intentions to relocate. This study draws upon the existing research on residential satisfaction to understand the shifts in the satisfaction of the local communities influenced by Rohingya migration. Using an indexing method, it compares the satisfaction of communities living near the Rohingya camps with those farther away across various residential satisfaction indicators to assess the nature and extent of the impact of the Rohingya influx on host communities. Furthermore, it examines how future migration intention varies between the communities, analysing the predictors of residential satisfaction to determine their effect, if any, on such decisions.

The structure of the paper is as follows. Initially, "Background" outlines the residential satisfaction concept and its application to various contexts in existing research. It also outlines existing research on the effect of forced migration on host communities. Next, "Methodology" elaborates on the research design, including the study area, the residential satisfaction indicators employed in the study, and the methods of data collection and analysis used. "Results" presents the results obtained. Finally, "Discussion" provides an overview of the findings and their implications regarding the impact of the Rohingya influx on host communities in Bangladesh.

\section{Background}

\section{Residential Satisfaction Concept and Its Relevance}

Residential satisfaction has been conceptualised in two major ways in the literature: firstly, as a principle of estimating residential attributes and quality, and secondly, as a predictor of housing mobility (Weidemann \& Anderson, 1985). Overall, it refers to the perception, feeling, and consciousness of one's place of residence (Cutter, 2008), describing residential quality of life and its subsequent effect on mobility (Amérigo \& Aragones, 1997). Residential satisfaction has been considered as a product of two key dimensions: the (1) physical, "consistent with 
the equipment and services" and (2) the social, "mentioning the social networks" (Amérigo \& Aragones, 1997). In this regard, it is the assessment of the social environment and physical characteristics together (Mesch \& Manor, 1998). Under this affective conceptualisation of residential satisfaction, the satisfaction level is determined by the assessment of certain objective features of the residential environment by the individual (Amerigo, 1992). These features are evaluated by the individual, becoming subjective, and resulting in some degree of satisfaction (Amérigo \& Aragones, 1997). Here, the subjective measurement includes one's perception, gratification, aspirations, and also dissatisfaction, which are strongly linked to an individual's psychological aspect (Mohit et al., 2010). This evaluation is affected by socio-demographic, environmental, and individual features, as well as 'residential quality pattern', a normative component that compares the individual's actual and ideal housing environment (Amérigo \& Aragones, 1997; Mohit et al., 2010;). Similarly, Aulia \& Ismail (2013) state that both physical (location of the house, quality of the house, and public facilities) and non-physical attributes (social interaction, security, and housing tenure) are significant influences on residential satisfaction (Biswas et al., 2021). On the whole, it can be said that residential satisfaction varies with the changes of physical and nonphysical aspects alike (Gan et al., 2019).

Regarding its influence on housing mobility, Jiang et al. (2017) have found that residential satisfaction significantly influences the propensity to stay; in other words, the lower the residential satisfaction, the higher the intention towards mobility. Likewise, Liao (2004) states that the propensity to mobility is strongly influenced by residential satisfaction and emotional attachment, as well as that the aspiration for greater residential satisfaction is an essential motive in the process of migration decisions. Amongst the variables contributing to residential satisfaction, demographic attributes such as age, marital status, level of education, and presence of children are significantly associated with propensity to mobility (Liao, 2004). Barcus (2004) finds that the residential satisfaction of urban-rural migrants varies across different age groups and other socio-demographic variables; and Wu (2006), Kim et al. (2015), and Jiang et al. (2017) note that elderly people are less likely to migrate compared to other age groups due to a lower residential satisfaction. Conversely, Li (2004) has found that life cycle events, such as marriage and childbirth, have a negligible impact on residential mobility. According to Day (2013), an increase in commute time reduces residential satisfaction levels, in turn motivating relocation. Tenure is an important variable affecting mobility decisions, as people have to find a cheaper residence as housing expenditures rise (Tao, et al., 2015). Likewise, household ownership and length of stay are shown to be important factors in the choice of residence and its satisfaction (Aulia \& Ismail, 2013). Household income and the household head's occupation, as socio-economic variables, also affect both the housing satisfaction and migration decisions of households (Aulia \& Ismail, 2013; Barcus, 2004; Liao, 2004.) Previous studies have found that both physical attachment, such as ownership of a house and length of residence, and social bonding, such as presence of relatives and friends who are treated as supporters in both financial and social commitments, might inflect residential satisfaction and hinder the decision to migrate (Bach \& Smith, 1977; Deane, 1990; Speare et al., 1982). 
Overall, many studies have sought to understand residential satisfaction and housing mobility in developed and developing countries, employing a range of analytical and methodological approaches to the residential satisfaction concept. The residential satisfaction of elderly people (Rioux \& Werner, 2011; Rojo-Perez et al., 2001) and, less commonly, students (Amole, 2009) has been studied. Notably, studies have examined residential satisfaction amongst residents of specific housing types, such as lower-cost public and social housing (e.g. Amérigo \& Aragonés, 1990; Byun \& Ha, 2016; Dekker et al., 2011; Mohit et al., 2010) and informal housing (e.g. Li \& $\mathrm{Wu}, 2013$; Mudege \& Zulu, 2011), often with an eye to the differences between housing types (e.g. Hourihan, 1984) and the housing experiences of economic migrants (e.g. Tao et al., 2014). With regard to migrants, involuntary displacement amongst urban residents is shown to have variable impacts on residential satisfaction, contrary to some perceptions based on satisfaction criteria in developed countries (Day, 2013; Li \& Song, 2009). However, Adams and Kay (2019) emphasise that the individual stress of climate-vulnerable people influences residential satisfaction and propensity to mobility. For forced migrants urgently fleeing strife, the barrier for satisfaction may be lower than for economic migrants (Mudege \& Zulu, 2011). It is noted that in such low-income contexts the determinants of residential satisfaction may be less evident, and mobility impeded regardless of satisfaction levels (Mudege \& Zulu, 2011). There has been limited research, on the other hand, of the influence of migration on the residential satisfaction of host communities, making the present study a novel application of the residential satisfaction concept. Few studies have also been conducted regarding residential satisfaction in Bangladesh, particularly with regard to mobility intentions. Mridha and Moore (2011) explore the effect of neighbourhood quality to find that physical dwelling attributes may be less likely to influence satisfaction than wider socio-physical predictors; Mridha (2020) examines the influence of demographic characteristics on residential satisfaction in Dhaka, finding significant relationships with age, gender, and marital status. The present study contributes to the literature on residential satisfaction by exploring how forced migration may influence residential satisfaction for host communities in Bangladesh. It examines both the effects of the Rohingya influx on locals' residential satisfaction, and further considers residential satisfaction factors as an explanatory variable for their changing mobility intentions.

\section{The Impact of Migration on Host Communities}

Research on the impacts of migration typically focuses on migrants themselves; however, there have been various assessments of the relations between hosts and migrants in the context of forced migration. Crucially, migration risks presenting an economic burden on host communities (Martin, 2005). In an empirical review of the major displacement crises from the past century, Verme and Schuettler (2021) find that the economic impacts of forced migration on host communities are largely short term and unlikely to be significant; however, when significant, they tend to negatively impact young, female, low-skill, and informal workers. Nevertheless, with the majority of forced displacement crises affecting developing countries, the effects are 
highly variable depending on the existing conditions and capacity of the community or country to manage such events (Maystadt et al., 2019). Thus, they may have longlasting consequences on the community's economic trajectory. Migration events may also have positive influences, such as fostering civic engagement amongst the host community and personal bonds between the communities (Mackreath, 2014). The key adverse impacts of mass migration on host communities in developing countries are environmental degradation, resource scarcity, and consequent competition over resources, as well as concerns regarding security and crowding (Ali et al., 2017). The complex social and economic dynamics of a host area may give rise to a range of positive and negative effects. For example, the host community in Turkana, Kenya, may have gained nutritional benefits as a result of refugee trade networks; however, perceptions of refugees as intruders and strains on the already poor community still persist (Gengo et al., 2017).

These studies contend that policies and aid programmes should focus on the codevelopment of migrants' and host communities' economic resilience and social well-being (Ali et al., 2017; Kumssa \& Jones, 2014); this is especially important in regions with weak institutional presence, and where both groups exist in precarity. In the case of resource environmental and competition, for example, shared, participatory community management of the resources may be a more holistic strategy (Martin, 2005). Existing research on the relations between Bangladeshi host communities and Rohingya migrants identifies a potential for greater future social conflict (Jerin \& Mozumder, 2019), and highlights the negative socio-economic impact of the influx on host communities' livelihood conditions (Ullah et al., 2021) as well as on wider regional industries like tourism (Ahmad \& Naeem, 2020). By systematically employing the residential satisfaction concept and comparing between more affected and less affected communities, the present research explores these livelihood and lifestyle effects in greater detail. It also pulls further migration, this time of the host community, into the picture, examining how forced migration could propel a chain of migration.

\section{Methodology}

\section{Study Area}

Cox's Bazar, a district of Chittagong division, borders the Bay of Bengal, the largest delta in the world. It consists of 8 Upazilas, 71 Unions, 177 Mauzas, 989 Villages, 4 Paurashvas, 39 Wards, and 169 Mahallas (Bangladesh Network, 2015). The eight Upazilas of the Cox's Bazar district are Chakaria, Cox's Bazar Sadar, Kutubdia, Maheskhali, Pekua, Ramu, Tekhnaf, and Ukhiya (BBS, 2011). For the assessment of host communities' residential satisfaction and intention to relocate in the face of the influx of Rohingya, the Ukhiya Upazila has been selected because a large number of Rohingya are present in this area, with Ramu Upazila as a basis for comparison. The Ukhiya Upazila consists of five Unions, with a total area of 261.8 square kilometres and a total population of 241,140 across 44,128 households (Banglapedia, 2015). 
Ukhiya Upazila hosts the largest refugee camp in the world, Kutupalong. Over $85 \%$ of Rohingya migrants in Bangladesh live in this Upazila (GFDRRR, 2018) making it a prime location for studying the effect of the Rohingya influx on the Bangladeshi population. For data collection, the village of Kutupalong, in Raja Palong Union, and Purba Balukhali, in Palong Khali Union, were selected, as they are both less than $1 \mathrm{~km}$ away from the camp. Furthermore, to help investigate the changes in the host communities' residential satisfaction, the village of Jungle Dhoya Palong, Khuniapalong Union, and Char Para (Caynda), Daskmin Mithachhari Union in Ramu Upazila were selected for comparison (Fig. 1 and Table 1). These villages are $15.92 \mathrm{~km}$ and $29.43 \mathrm{~km}$ away from Kutupalong, respectively, and thus not directly affected by the Rohingya presence as Ukhiya is. However, it was assumed that as these areas are situated in the same zone overall, their geographical and demographic characteristics would be similar. Thus, they can provide a reasonable basis for comparison to estimate the satisfaction of

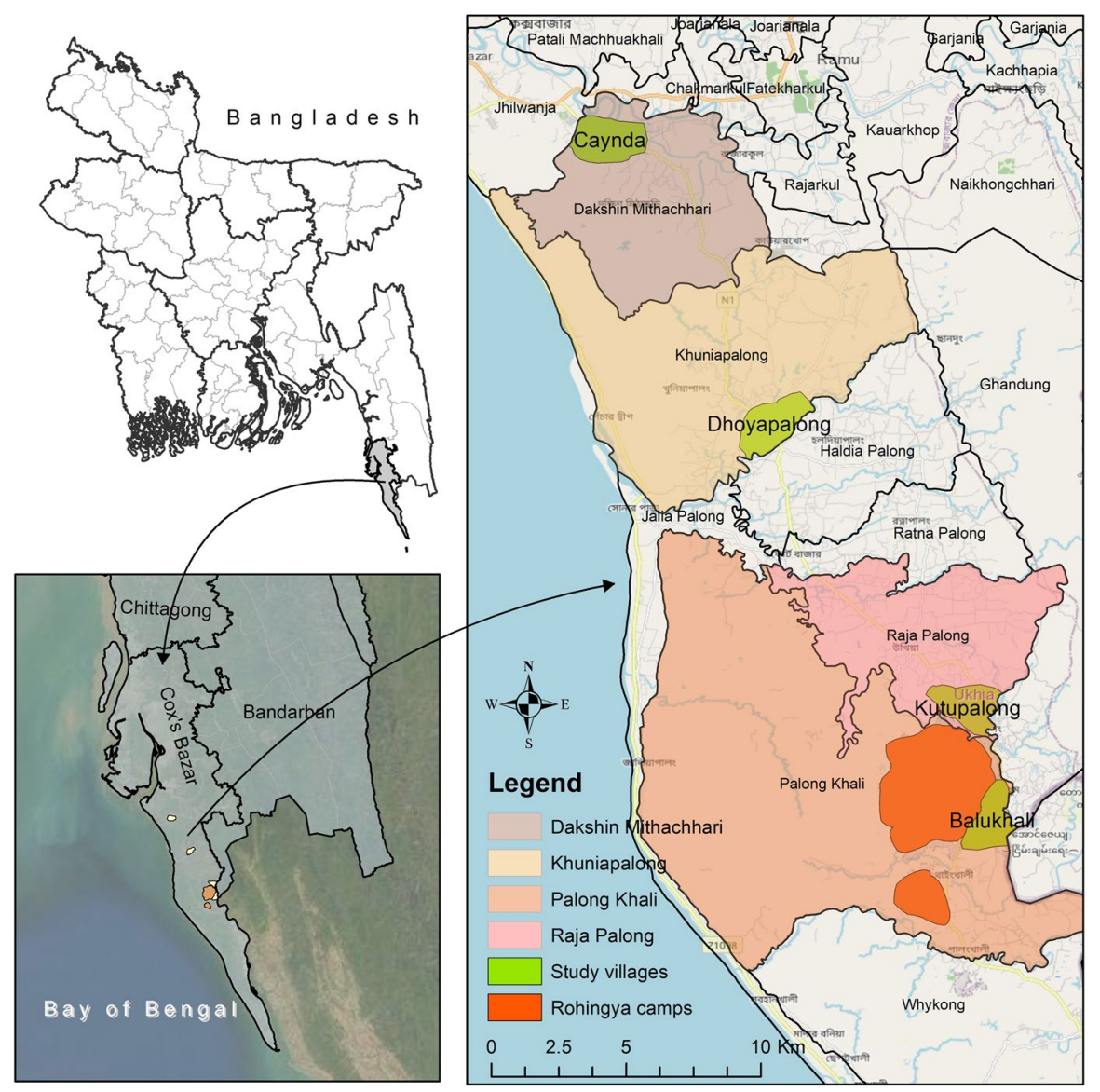

Fig. 1 Map of the study area in Cox's Bazar District. Source: Authors' illustration 
Table 1 Study villages and the distance from the camp areas, and sample distribution

\begin{tabular}{llllll}
\hline Upazila & Union & Villages (Mouza) & $\begin{array}{l}\text { Sample } \\
\text { households }\end{array}$ & $\begin{array}{l}\text { Total } \\
\text { households }\end{array}$ & $\begin{array}{l}\text { Distance } \\
\text { from camp } \\
\text { areas }\end{array}$ \\
\hline Ukhiya & Raja Palong & Kutupalong & 53 & 858 & 0.85 \\
& Palong Khali & Purba Balukhali & 63 & 409 & 0.42 \\
Ramu & Khuniapalong & Jungle Dhoya Palong & 17 & 270 & 15.92 \\
& & (Dhoya Palong) & & 147 & 29.44 \\
\hline
\end{tabular}

Authors' compilation, 2019.

Ukhiya residents prior to the Rohingya influx, and thus the effect of the influx on their current perceptions.

The average literacy rate of Ukhiya is $28 \%$, and the predominant source of income amongst the population is agriculture (Banglapedia, 2015). Most people are engaged in producing various products such as rice, pulses, vegetables, nuts, cereals, rubber, sugarcane, tobacco, and more. Along with this, a large number of people provide services such as day labourers, drivers, and shopkeepers (Bangladesh Network, 2015). Prior to the Rohingya mass migration, Ukhiya Upazila was already lagging behind the national average in terms of its public services and infrastructure (HDX, 2019). With the onset of the Rohingya influx, the already vulnerable infrastructure experienced massive pressures. Local workers also reported being undercut by cheaper Rohingya labour, and lamented that food prices had quickly shot up. For example, the price of onions and potatoes had risen to be 15 taka ( $\sim$ US 0.20) higher than in Dhaka within 2 weeks (Dey, 2018).

\section{Data Collection}

Applying the systematic random sampling method, 151 households in total were interviewed face to face. The interview was conducted using a pre-prepared survey questionnaire designed to collect both quantitative and qualitative data. To investigate the present situation of the Ukhiya host communities living nearer to the camp area, 116 household heads were interviewed. Furthermore, to examine actual changes in different aspects of residential satisfaction and provide a basis for comparison with Ukhiya, 35 household heads were interviewed randomly from the Jungle Dhoya Palong and Char Para (Caynda) villages, located in Ramu. As said earlier, we consider that proximity to Rohingya camps increases residential dissatisfaction, thereby motivating aspirations to migrate in the future. Therefore, we have selected four communities and with varying proximities to the camp area: the first is less than $0.5 \mathrm{~km}$ away, the second is under $1 \mathrm{~km}$ away, the third is around $15 \mathrm{~km}$ away, and the fourth one is almost $30 \mathrm{~km}$ away from the camps. We selected respondents from every 5 or 6 households from the closest and farthest communities, whereas we selected respondents from every 15 or 16 households from the second and third farthest communities. If someone declined to participate in the survey, we moved to the 
next household in turn. Our sample represents about $9-10 \%$ of the total households living in the selected communities. In each case, we selected respondents by starting from a central point in the community i.e. a marketplace or school. We divided our field team, who then travelled along the main access roads of the selected community, and requested interviews from households at the intervals described earlier.

The final face-to-face interview i.e. household survey data was collected from 23 September to 4 October 2019. Before the final household survey, a pilot study was conducted to check how well the prepared questionnaire served the real situation in this study area. In this session, four schoolteachers, two residents living close to Rohingya camp area, and one NGO worker serving as a doctor for the Rohingya were interviewed. Mainly, they were asked (1) Do you think everything is going well in the surrounding area in the aftermath of the Rohingya influx? (2) How satisfied are you in the aftermath of the Rohingya influx in this region? (3) Do you intend to leave this place, either temporary or permanently?; and (4) Do you know anyone (neighbours/friends/relatives) who wants to relocate?

In order to collect data with a semi-structured questionnaire, all questions were set up in KoBoToolbox, and data was collected using smartphones. Each interviewed lasted around 20-25 min on average, during which the survey was administered. After completing the data collection session, the Excel file of the raw data was downloaded from the KoBoToolbox.org server and prepared for data analysis.

\section{Indicators of Residential Satisfaction and Mobility}

Residential satisfaction is a broad concept that has been operationalised in a number of ways in the literature depending on the study area and parameters. Generally, the indicators that potentially influence residential satisfaction have been grouped into key categories regarding the immediate dwelling design, wider neighbourhood environment and services, and the social environment of the study area in question (Biswas et al., 2021; Buys \& Miller, 2012; Mohit et al., 2010). A selection of variables were chosen for assessment in this study, following consideration of the study area, scope, and a review of existing studies of residential satisfaction. These items were grouped into five categories and used to develop a questionnaire. Table 2 presents the chosen variables of residential satisfaction with their citations in preceding literature.

\section{Measurement of Residential Satisfaction}

Based on the literature review, the components of residential satisfaction were categorized into four factors: (1) satisfaction with social environment (SSE), (2) satisfaction with neighbourhood environment (SNE), (3) satisfaction with public services and facilities (SPS\&F), and (4) satisfaction with dwelling units (SDU). To measure the satisfaction level of the Ukhiya host communities, a Likert scale with five points was used. In this scale, "1" was assigned for very dissatisfied, "2" for dissatisfied, "3" for indifferent, " 4 " for satisfied, and "5" for very satisfied. Following the estimation technique of Mohit et al. (2010), the residential satisfaction of the Ukhiya 


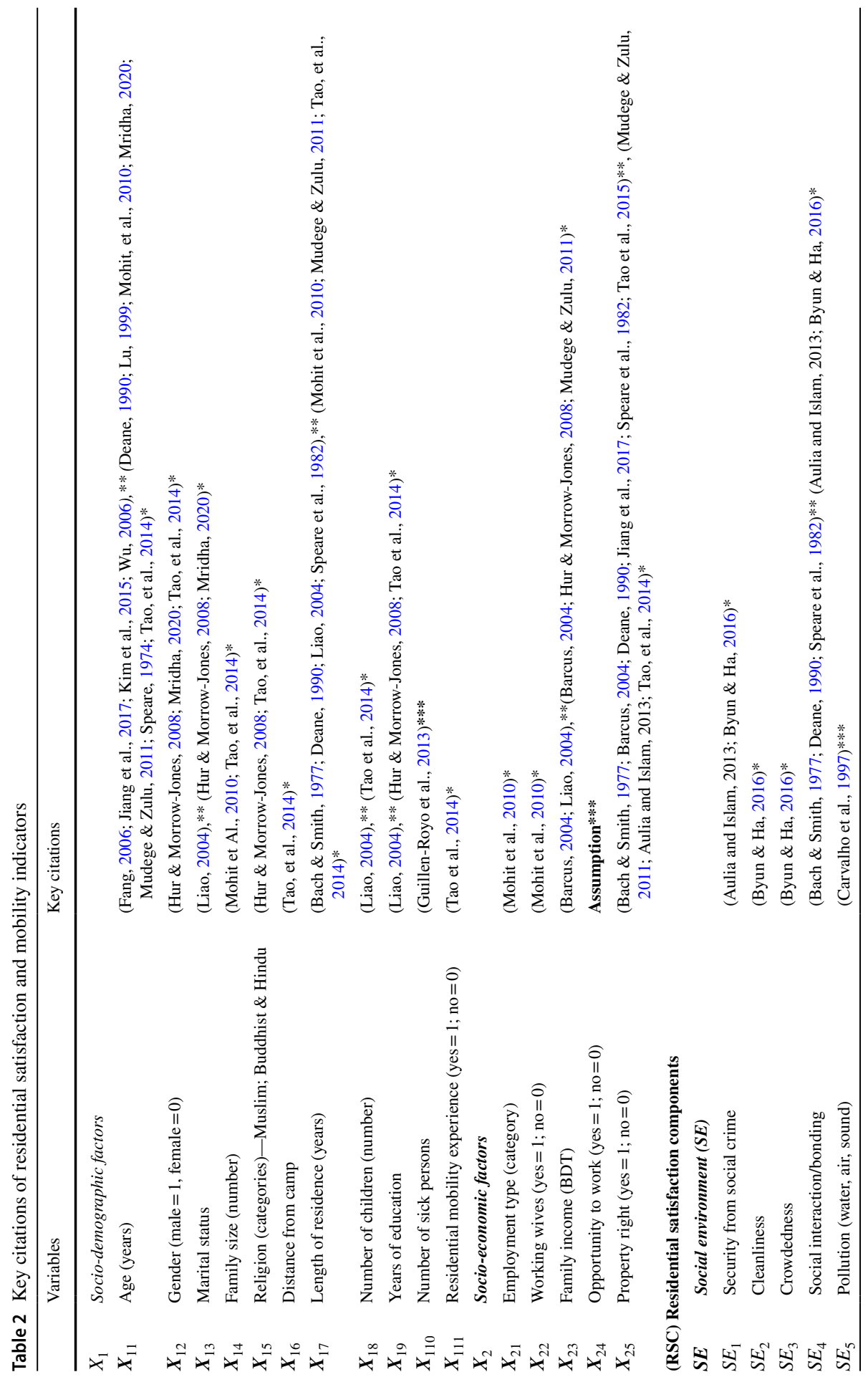




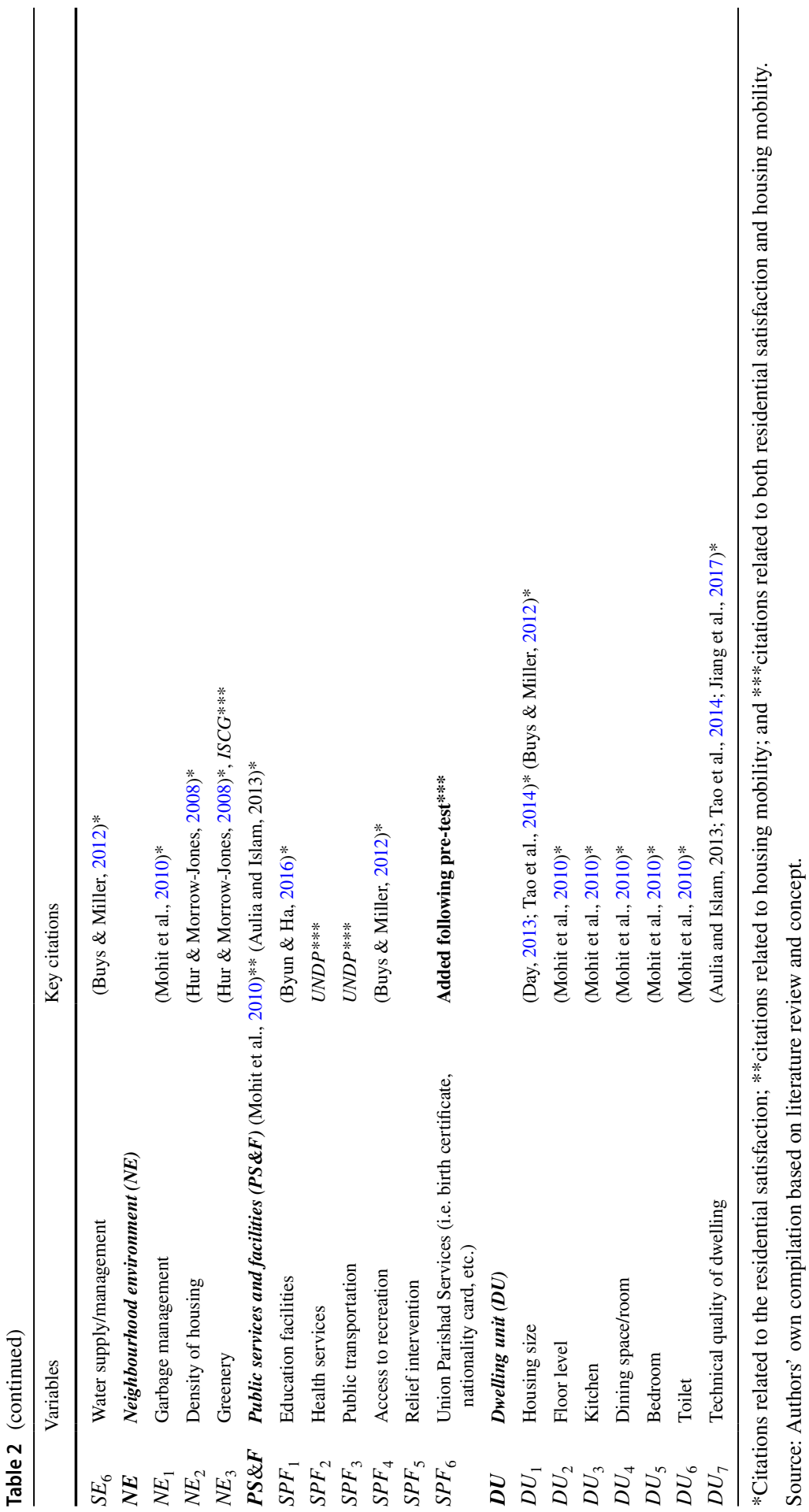


host communities was estimated in the two stages which are shown in the following equations.

Stage 1: In this stage, the satisfaction level of each component for each household has been estimated separately.

\section{Residential Satisfaction Index of the Particular Component}

$$
S I_{c}=\frac{\sum_{j=1}^{N} y_{j}}{\sum_{j=1}^{N} Y_{j}} \times 100
$$

where,

$S I_{c}=$ represents the satisfaction index of the respondents with a particular component (c).

$N=$ represents the number of variables of the particular component.

$y_{j}=$ represents the score obtained by the respondents on the $j^{\text {th }}$ variables under that component.

$Y_{j}=$ represents maximum possible score on the $j^{\text {th }}$ variables under that particular component.

From Eq. 1, the respondent's residential satisfaction score for the four residential satisfaction components is estimated. In the first component, satisfaction with social environment, six variables; in the second component, satisfaction with neighbourhood environment, three variables; in the third component, satisfaction with public services and facilities, six variables; and in the last component, satisfaction with dwelling units, seven variables, have been considered to estimate the residential satisfaction separately.

Stage 2: Adding all categories, the overall residential satisfaction level has been calculated.

\section{Residential Satisfaction Index}

$$
S I_{r}=\frac{\sum_{j=1}^{N 1} s d u_{j}+\sum_{j=1}^{N 2} s n e_{j}+\sum_{j=1}^{N 3} s s e_{j}+\sum_{j=1}^{N 4} s p s f_{j}}{\sum_{j=1}^{N 1} S D U_{j}+\sum_{i=1}^{N 2} S N E_{j}+\sum_{j=1}^{N 3} S S E_{j}+\sum_{j=1}^{N 4} S P S F_{j}} \times 100
$$

where,

$S I_{r}=$ the overall residential satisfaction index of a respondent; $N 1 \ldots \ldots . . N 4=$ the number of variables under the particular component of the residential environment; the symbols $s d u_{j}, s n e_{j}, s s e_{j}$, and $s p s f_{j}$ represent the actual score of an individual on the $j^{\text {th }}$ variables in the four residential environment components respectively; whereas, the symbols $S D U_{j}, S N E_{j}, S S E_{j}$, and $S P S F_{j}$ represent the maximum possible score for the $j^{\text {th }}$ variables in the four components.

\section{The Ordinal Logistic Regression Model}

In this study, the role of residential satisfaction on the relocation decision of the host communities affected by the Rohingya influx has additionally been investigated. As 
at present time, the future of the Rohingya settlement is ambiguous, so it is hypothesized that some people may think to relocate temporarily. The intention to relocate of the communities has been estimated by asking questions regarding their likelihood to move from their current place $(1,2,3$, and 4 are coded for very unlikely, unlikely, likely, and very likely respectively). However, to estimate the impact of various factors on the intention to relocation, an ordinal logistic regression has been applied. As the dependent variables are in an ordered pattern and consist of more than two outcomes, the ordinal logistic regression model is suitable. This regression model is the following:

$$
I M_{i k}=\ln \left(\frac{p_{i}}{1-p_{i}}\right)=\beta_{0}+\beta_{1 j} \sum_{j=1}^{11} X_{1 i j}+\beta_{2 j} \sum_{j=1}^{5} X_{2 i j}+\beta_{3} S I_{i}+\beta_{4 j} \sum_{j=1}^{4} R S C_{i j}+u_{i}
$$

where,

\section{$i=1,2,3,,,,,,,,,, n ; j=1,2,3,,,,,,,,,, m$}

$I M_{i k}=$ represents the relocation intention.

$X_{1 i j}=$ represents the number of socio-demographic variables.

$X_{2 i j}=$ represents the number of socio-economic variables.

$S I_{i}=$ represents the score of the residential satisfaction of the $i^{\text {th }}$ respondents.

$R S C_{i j}=$ represents the scores of the residential satisfaction components of the $i^{t h}$ respondents $\left(S I_{S S E i}, S I_{S N E i}, S I_{S P S \& F i}\right.$ and $\left.S I_{S D U i}\right)$.

$\beta_{0}=$ represents the intercept term.

$\beta_{1}, \beta_{2}$ and $\beta_{3}=$ represents the parameters.

$u_{i}=$ represents the error term.

where $k=1,2,3$, and 4 ( 1 coded for very unlikely; 2 for unlikely; 3 for likely; and 4 for very likely) and $\ln \left(p_{i} / 1-p_{i}\right)$ is the logit. The logit changed by $\beta_{i}$ in changes in independent variables $x_{i}$ by 1 unit. Here, the log of the odds ratio is linear in both $X_{i}$ and parameters.

To run the ordinal logistic regression model, three types of independent variables have been considered broadly. These are socio-demographic $\left(X_{1 i j}\right)$, socio-economics $\left(X_{2 i j}\right)$ variables and the composite variable residential satisfaction $S I_{i}=$ as well as the components of the residential satisfaction listed in Table 2. To see the individual effect of variables especially overall residential satisfaction and its components on intention to relocation as well as to avoid severe multicollinearity, the regression model was run five times. Using the heteroscedasticity-robust formulation, the standard errors for all five models were computed to correct the possible heteroscedasticity (Day, 2013).

$$
I M_{i k}=\ln \left(\frac{p_{i}}{1-p_{i}}\right)=\beta_{0}+\beta_{1 j} \sum_{j=1}^{8} X_{1 i j}+\beta_{2 j} \sum_{j=1}^{3} X_{2 i j}+\beta_{3} S I_{i}+u_{i}
$$




$$
\begin{gathered}
I M_{i k}=\ln \left(\frac{p_{i}}{1-p_{i}}\right)=\beta_{0}+\beta_{1 j} \sum_{j=1}^{8} X_{1 i j}+\beta_{2 j} \sum_{j=1}^{3} X_{2 i j}+\beta_{31} S I_{S S E i}+u_{i} \\
I M_{i k}=\ln \left(\frac{p_{i}}{1-p_{i}}\right)=\beta_{0}+\beta_{1 j} \sum_{j=1}^{8} X_{1 i j}+\beta_{2 j} \sum_{j=1}^{2} X_{2 i j}+\beta_{32} S I_{S N E i}+u_{i} \\
I M_{i k}=\ln \left(\frac{p_{i}}{1-p_{i}}\right)=\beta_{0}+\beta_{1 j} \sum_{j=1}^{7} X_{1 i j}+\beta_{2 j} \sum_{j=1}^{4} X_{2 i j}+\beta_{33} S I_{S P S \& F i}+u_{i} \\
I M_{i k}=\ln \left(\frac{p_{i}}{1-p_{i}}\right)=\beta_{0}+\beta_{1 j} \sum_{j=1}^{9} X_{1 i j}+\beta_{2 j} \sum_{j=1}^{4} X_{2 i j}+\beta_{34} S I_{S D U i}+u_{i}
\end{gathered}
$$

Initially, in Eq. 4 (model 1), eight socio-demographic variables were incorporated: age $\left(X_{11}\right)$, gender $\left(X_{12}\right)$, family size $\left(X_{14}\right)$, residential status $\left(X_{17}\right)$, the number of children $\left(X_{18}\right)$, education level $\left(X_{19}\right)$, number of sick persons $\left(X_{110}\right)$, and mobility experiences $\left(X_{111}\right)$, plus the three socio-economic variables: working wives $\left(X_{22}\right)$, the opportunity to work $\left(X_{24}\right)$, and property rights $\left(X_{25}\right)$. Plus, the composite variable residential satisfaction was included to see the impact of it on the people's relocation intention. Secondly, in Eq. 5 (model 2), the eight socio-demographic variables and three socio-economics variables were included. The composite variable "satisfaction with social environment" $\left(S I_{S S E i}\right)$ also was considered, and others kept outside the model, to find the impact of this variable on the relocation intention. Equation 6 represents regression model 3 . The same number of socio-demographic and socio-economic variables were taken, along with the neighbourhood environment component $\left(S I_{S N E i}\right)$, to assess its impact on relocation intention.

Similarly, model 4 has been run stepwise as presented in Eq. 7. It was assumed there might be a correlation between the education level $\left(X_{19}\right)$, employment types $\left(X_{21}\right)$, and monthly income $\left(X_{26}\right)$ of the families. The people who are more educated might have more formal employment in the camp area and thus earn more. So, excluding the education and household income variables, the impact of employment type on residential satisfaction has been assessed. A new socio-demographic variable religion $\left(X_{15}\right)$ was included in model 4 and the variables residential status $\left(X_{17}\right)$ and mobility experiences $\left(X_{111}\right)$ dropped from the model to reduce the linearity problem. The composite variable satisfaction with public services and facilities is added to explore its impact on relocation intentions. Finally, in model 5 (Eq. 8), the education and employment variables have been dropped while the monthly income $\left(X_{26}\right)$ is incorporated. A location variable $\left(X_{16}\right)$ denotes how the mobility intention varies across the distance from the camp area. Also, in this model, the impact of dwelling units on residential satisfaction has been assessed. 


\section{Results}

\section{Social, Demographic, and Economic Profile of the Surveyed Households}

The summary profile of the surveyed households is listed in Table 3 and divided under the three broad categories: socio-demographic, socio-economic, and residential satisfaction components.

The mean age of the respondents is about 43 with 19 as the minimum and 75 as a maximum. $70 \%$ of the total respondents were male and $30 \%$ female. Their average education level is around 6 years of schooling, with a maximum of 17 years of schooling, plus some respondents with no schooling. Sixty-two percent were Muslim, $14 \%$ Hindu, and $25 \%$ Buddhist, and $87 \%$ were living in their places of birth. During the survey, we observed that most of the households in this study area do not have separate spaces for their kitchen and bedroom, and after dividing joint families, we found that multiple families even live in the same house. The average number of children in each family is about 2.05. The surveyed households of the Ukhiya host communities are living on average $0.62 \mathrm{kms}$ away from the Kutupalong camp, whereas the non-Ukhiya residents are living $22.77 \mathrm{kms}$ away. Empirical analysis found that about $9 \%$ of respondents have prior migration experiences.

The findings from raw data analysis show that $15 \%$ of household heads are engaged in formal jobs with the Government, NGOs, and companies, while the remainder are involved in various informal jobs as day labourers, drivers, farmers, tailors, barbers, etc. Around $66 \%$ of people postulated that, in the aftermath of the Rohingya influx, their work opportunities have declined, whereas $22 \%$ and $13 \%$ felt their work opportunities have remained the same or increased, respectively. The average income and consumption are 13,536 BDT (170 USD) and 10,670 BDT (135 USD) per month, respectively. Approximately $15 \%$ of household heads' wives were involved in work outside the home to support their families. Although $87 \%$ of household heads were living in their area by birth, $13 \%$ had shifted their residence. In addition, results show that about $6 \%$ of the total sample of households don't hold any property rights and are living on public land. This is government-owned land which they do not have the right to sell.

To assess the residential satisfaction of the host community following the influx of Rohingya, a total of 22 residential environmental factors were categorized into four components. The value of the satisfaction index ranges from 0 to 100 . The score value of the components is presented in Table 3 and demonstrates that the people are relatively more dissatisfied with the neighbourhood environment (43.62), public services and facilities (44.75), and social environment (48.17), compared to dwelling units (60.66).

\section{Residential Satisfaction Components Across Communities}

Mean comparison of the residential satisfaction predictors under the four components for the communities nearer to the camp area and communities farther from 


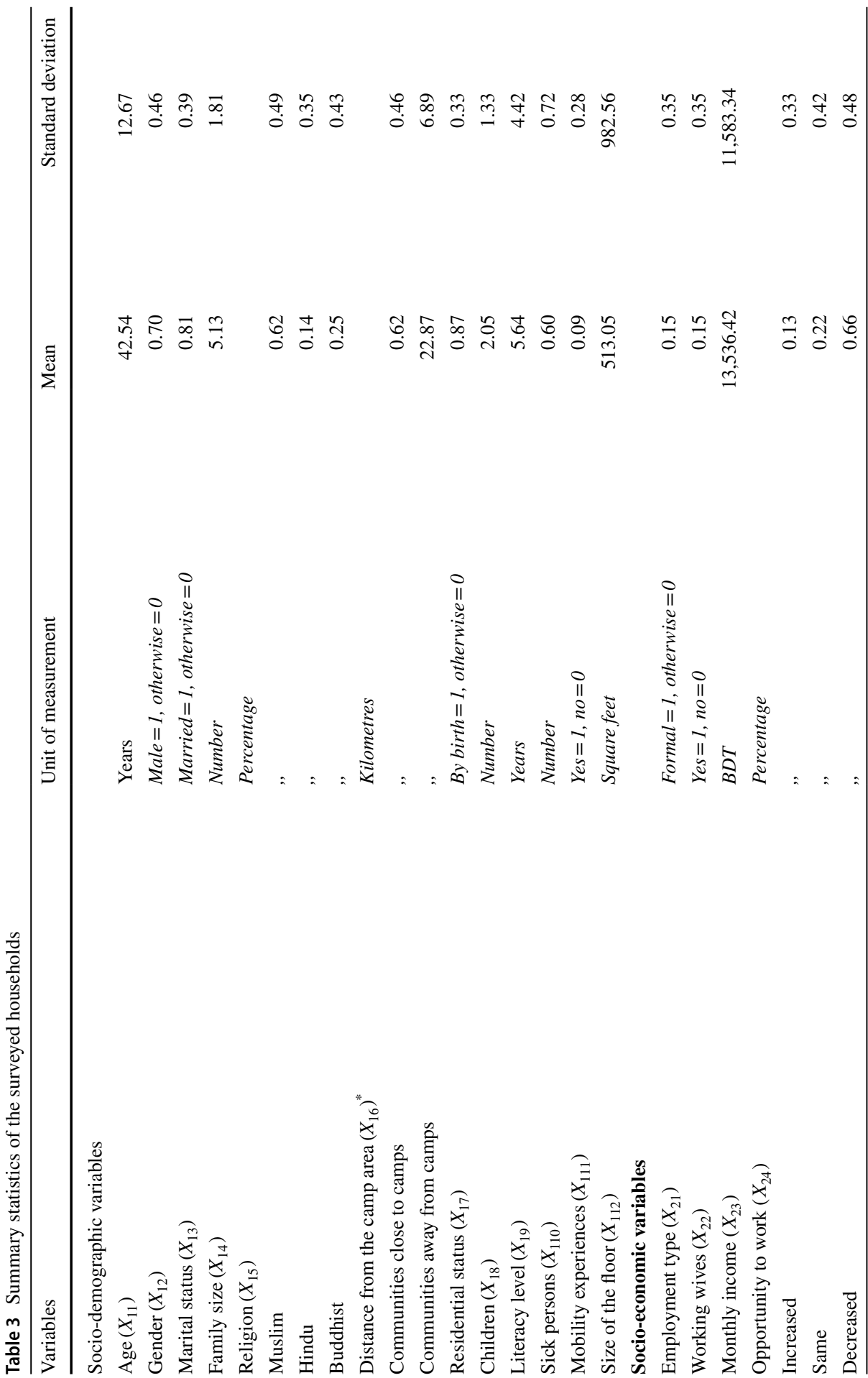




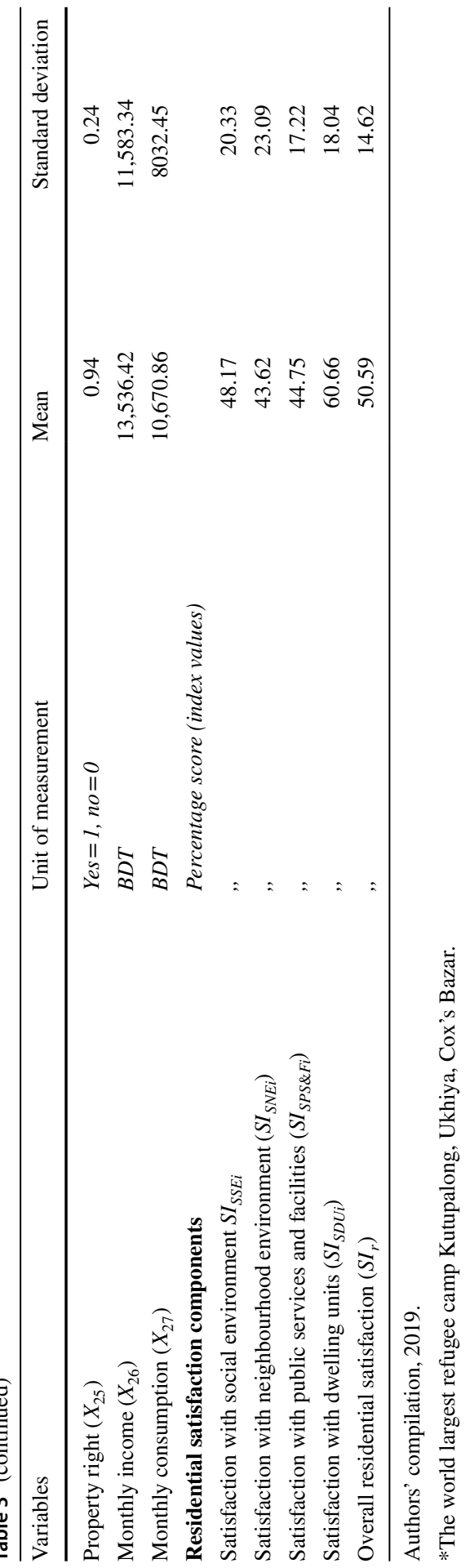


Table 4 Mean difference of residential satisfaction variables

\begin{tabular}{|c|c|c|c|c|c|c|}
\hline $\begin{array}{l}\text { Residential satisfaction } \\
\text { component }\end{array}$ & $\begin{array}{l}\text { Communities } \\
\text { close to camp } \\
(N=116)\end{array}$ & Std & $\begin{array}{l}\text { Communi- } \\
\text { ties distant } \\
\text { from camp } \\
(N=35)\end{array}$ & Std & Mean diff & $t$-value \\
\hline \multicolumn{7}{|c|}{ Satisfaction with the social environment } \\
\hline $\begin{array}{l}\text { Security against social } \\
\text { crime }\end{array}$ & 1.67 & 1.02 & 3.60 & 1.12 & -1.93 & $-9.59 * * *$ \\
\hline Cleanliness & 1.78 & 0.92 & 4.00 & 0.64 & -2.22 & $-13.27 * * *$ \\
\hline Crowdedness & 1.59 & 0.76 & 4.03 & 0.62 & -2.44 & $-17.38 * * *$ \\
\hline Social bonding & 3.14 & 1.10 & 4.23 & 0.60 & -1.09 & $-5.60 * * *$ \\
\hline Pollution & 1.54 & 0.64 & 3.83 & 0.79 & -2.29 & $-17.57 * * *$ \\
\hline Water supply & 1.97 & 0.99 & 3.91 & 0.66 & -1.95 & $-10.96^{* * *}$ \\
\hline Index $=S I_{S S E}$ & 38.97 & 12.05 & 78.67 & 9.26 & -39.70 & $-17.94 * * *$ \\
\hline \multicolumn{7}{|c|}{ Satisfaction with the neighbourhood environment } \\
\hline Garbage management & 1.77 & 0.73 & 3.94 & 0.68 & -2.18 & $-15.73 * * *$ \\
\hline Density of housing & 1.65 & 0.71 & 3.91 & 0.51 & -2.27 & $-17.50 * * *$ \\
\hline Greenery & 1.43 & 0.59 & 4.31 & 0.80 & -2.88 & $-23.18 * * *$ \\
\hline Index $=S I_{S N E}$ & 32.30 & 10.50 & 81.14 & 9.63 & -48.84 & $-24.57 * * *$ \\
\hline \multicolumn{7}{|c|}{ Satisfaction with public services and facilities } \\
\hline Education facilities & 1.88 & 1.08 & 3.80 & 0.76 & -1.92 & $-9.80 * * *$ \\
\hline Health services & 2.21 & 1.15 & 3.91 & 0.66 & -1.71 & $-8.39 * * *$ \\
\hline Public transport & 1.16 & 0.49 & 3.06 & 1.35 & -1.89 & $-12.65^{* * *}$ \\
\hline Access to recreation & 1.42 & 0.70 & 3.94 & 0.59 & -2.52 & $-19.32 * * *$ \\
\hline Relief intervention & 2.42 & 0.84 & 3.23 & 0.55 & -0.81 & $-5.36 * * *$ \\
\hline Union Parishad services & 1.96 & 1.07 & 3.34 & 0.91 & -1.39 & $-6.96 * * *$ \\
\hline Index $=S I_{S P S \& F}$ & 36.84 & 9.42 & 70.95 & 9.41 & -34.11 & $-18.79 * * *$ \\
\hline \multicolumn{7}{|c|}{ Satisfaction with dwelling units } \\
\hline Size of the floor & 2.98 & 1.31 & 3.69 & 0.80 & -0.70 & $-3.00 * * *$ \\
\hline Floor level & 3.33 & 1.34 & 4.06 & 0.42 & -0.73 & $-3.18 * * *$ \\
\hline Kitchen & 2.72 & 1.25 & 3.37 & 0.91 & -0.65 & $-2.85^{* * *}$ \\
\hline Dining space & 2.91 & 1.29 & 3.31 & 0.90 & -0.41 & $-1.76^{* *}$ \\
\hline Bedroom & 2.95 & 1.17 & 3.34 & 0.87 & -0.39 & $-1.84 * *$ \\
\hline Toilet & 2.81 & 1.48 & 3.03 & 1.18 & -0.22 & -0.80 \\
\hline Quality of the dwelling & 2.67 & 1.33 & 3.29 & 1.05 & -0.61 & $-2.50 * * *$ \\
\hline Index $=S I_{S D U}$ & 58.20 & 18.56 & 68.82 & 13.48 & -10.61 & $-3.14 * * *$ \\
\hline
\end{tabular}

$R S C$ residential satisfaction components.

***Significant at 0.01 level, **significant at 0.05 level, and *significant at 0.10 level.

Authors' compilation, 2019.

the camp area is presented in Table 4. The $t$-test value of the mean comparison table shows that the communities living away from the camp area are more satisfied with all six aspects of the social environment than the communities living closer to the camp area, and this is statistically significant at the $1 \%$ level. 
Similar results are found in the case of the mean comparison of neighbourhood environment issues. The negative $t$-values showed that the communities near the camp area are more dissatisfied with all three aspects of the neighbourhood environment than the communities who are living farther away from the camp area, and this is also statistically significant at the $1 \%$ level. Likewise, the mean values of the satisfaction with public services and facilities are higher for the residents living away from the camp area than the residents who are living adjacent to the camp area. This is also significant at the $1 \%$ level.

In the case of satisfaction with dwelling units, although all variables of the dwelling units except the toilet are also statistically significant, the mean comparison values are comparatively lower than for the other residential satisfaction components. Also, Table 4 demonstrates that the mean difference between the satisfaction score of the dwelling units is much lower compared to other residential satisfaction scores. This means that amongst the 4 components and 22 variables constituting residential satisfaction, the Ukhiya host communities are much more dissatisfied with the social environment, neighbourhood environment, and public services and facilities compared to dwelling units.

\section{Ranking of the Residential Satisfaction Factors}

A total of 22 residential satisfaction factors have been ranked based on the scores obtained from the respondents. The results, exhibited in Table 5, show that all seven residential satisfaction issues under the dwelling unit component rank amongst the first eight most satisfactory aspects: floor level $\left(1^{\text {st }}\right)$, floor size $\left(3^{\text {rd }}\right)$, bedroom $\left(4^{\text {th }}\right)$, dining space $\left(5^{\text {th }}\right)$, toilet $\left(6^{\text {th }}\right)$, kitchen $\left(7^{\text {th }}\right)$, and quality of dwelling $\left(8^{\text {th }}\right)$. During the field survey, it was found that most of the homes are built on small hills, which may be linked to higher satisfaction with the floor level than the other issues of residential satisfaction.

The lowest satisfaction score was for the transportation system, suggesting that public transport in this area is poor. Based on the respondent's opinions, and observations made while travelling in the study area, the increased population required more vehicles on the road, creating traffic jams. The result shows that the host communities are more dissatisfied with access to recreation, greenery, pollution, crowdedness, the density of housing, safety from social crime, garbage management of the neighbourhood, cleanliness of the area, and others as shown in Table 5. The qualitative analysis additionally highlights other crucial problems, such as price hike of commodities, lack of fuelwood, poor phone networks, and weak internet connection. Summarising the changes since the Rohingya influx, one respondent (local politician, 52 years old, from Purba Balukhali village) references various aspects of residential satisfaction, including the issues of noise pollution, recreation, social bonding, and crowdedness:

"Before Rohingya people were moving freely among the community, people were gossiping at the market place, youth used to play at the playground, neighbours visited nearby households frequently. My friends frequently visited my shop and we used to pass good quality time with a cup of tea. There were 
Table 5 Ranking of the residential satisfaction factors of the communities close to camp area $(N=116)$

\begin{tabular}{|c|c|c|c|c|c|c|c|}
\hline Rank & Residential satisfaction factors $(N=116)$ & VS (5) & S (4) & I (3) & $\mathrm{D}(2)$ & $\mathrm{VD}(1)$ & Total score \\
\hline $1^{\mathrm{st}}$ & Satisfaction with "Floor level" & 18.97 & 41.38 & 5.17 & 22.41 & 12.07 & 386 \\
\hline $2^{\text {nd }}$ & Satisfaction with "Community relationship" & 11.21 & 26.72 & 34.48 & 19.83 & 7.76 & 364 \\
\hline $3^{\text {rd }}$ & Satisfaction with "Floor size" & 9.48 & 41.38 & 1.72 & 32.76 & 14.66 & 346 \\
\hline $4^{\text {th }}$ & Satisfaction with "Bedroom" & 2.59 & 45.6 & 7.76 & 31.90 & 12.07 & 342 \\
\hline $5^{\text {th }}$ & Satisfaction with "Dining space" & 5.17 & 44.83 & 2.57 & 30.17 & 17.24 & 337 \\
\hline $6^{\text {th }}$ & Satisfaction with "Toilet" & 11.21 & 37.93 & 0.86 & 20.69 & 29.31 & 326 \\
\hline $7^{\text {th }}$ & Satisfaction with "Kitchen" & 3.45 & 37.94 & 5.17 & 34.48 & 18.97 & 316 \\
\hline $8^{\text {th }}$ & Satisfaction with "Quality of dwelling" & 5.17 & 37.07 & 1.72 & 31.90 & 24.14 & 310 \\
\hline $9^{\text {th }}$ & Satisfaction with "Relief intervention" & 0.86 & 3.45 & 49.14 & 30.17 & 16.38 & 281 \\
\hline $10^{\text {th }}$ & Satisfaction with "Health services" & 1.72 & 18.10 & 12.93 & 33.62 & 33.62 & 256 \\
\hline $11^{\text {th }}$ & Satisfaction with "Water supply" & 0.86 & 6.90 & 20.69 & 31.03 & 40.52 & 228 \\
\hline $12^{\text {th }}$ & Satisfaction with "Union parishad services" & 3.45 & 6.03 & 15.52 & 32.76 & 42.24 & 227 \\
\hline $13^{\text {th }}$ & Satisfaction with "Education facilities" & 1.72 & 11.21 & 8.62 & 30.17 & 48.28 & 218 \\
\hline $14^{\text {th }}$ & Satisfaction with "Cleanliness of the area" & 1.72 & 3.45 & 12.93 & 35.34 & 46.55 & 207 \\
\hline $15^{\text {th }}$ & Satisfaction with "Garbage management" & 0.00 & 2.59 & 9.48 & 50.00 & 37.93 & 205 \\
\hline $16^{\text {th }}$ & Satisfaction with "Safety from social crime" & 0.86 & 8.62 & 9.48 & 18.97 & 62.07 & 194 \\
\hline $17^{\text {th }}$ & Satisfaction with "Density of housing" & 0.00 & 1.72 & 8.62 & 42.24 & 47.41 & 191 \\
\hline $18^{\text {th }}$ & Satisfaction with "Crowdedness" & 0.00 & 2.59 & 8.62 & 33.62 & 55.17 & 184 \\
\hline $19^{\text {th }}$ & Satisfaction with "Pollution" & 0.00 & 0.00 & 7.76 & 38.79 & 53.45 & 179 \\
\hline $20^{\text {th }}$ & Satisfaction with "Greenery scenario" & 0.00 & 0.00 & 5.17 & 32.77 & 62.07 & 166 \\
\hline $21^{\mathrm{st}}$ & Satisfaction with "Access to recreation" & 0.00 & 2.59 & 4.31 & 25.86 & 67.24 & 165 \\
\hline $22^{\text {nd }}$ & $\begin{array}{l}\text { Satisfaction with "Public transportation } \\
\text { system" }\end{array}$ & 0.00 & 0.862 & 2.59 & 8.62 & 87.93 & 135 \\
\hline
\end{tabular}

$V S$ very satisfied, $V$ satisfied, $I$ indifferent, $D$ dissatisfied, and $V D$ very dissatisfied.

Authors' compilation, 2019.

not many noises, as well. But certainly, the whole scenario has changed. The market is always full of thousands of unknown people, a huge number of people came to this place for job purposes and created extra pressure on the residents as well as on our social culture. Playgrounds seem almost empty most of the time because most of the youth are engaged with economic activities instead of physical exercise or study."

\section{Residential Satisfaction Index}

The residential satisfaction scores are obtained from the residential satisfaction index presented in Eq. 2. The third column of Table 6 shows that the mean satisfaction score of the communities close to the camp area is around 43.60, with 22.73 as the minimum and 62.73 as the maximum. On the contrary, the mean satisfaction score of the communities away from the camp areas is about 73.77 with a minimum of 63.64 and a maximum of 85.45. The satisfaction of the more significant number 
Table 6 Distribution of the residential satisfaction scores

\begin{tabular}{lllll}
\hline Residential satisfaction & $\begin{array}{l}\text { Communities close to } \\
\text { camp areas }(N=116)\end{array}$ & $(\%)$ & $\begin{array}{l}\text { Communities distant from } \\
\text { camp areas }(N=35)\end{array}$ & $(\%)$ \\
\hline $20 \leq \mathrm{RS}<30$ & 5 & 4.31 & 0 & 0.00 \\
$30 \leq \mathrm{RS}<40$ & 34 & 29.31 & 0 & 0.00 \\
$40 \leq \mathrm{RS}<50$ & 57 & 49.14 & 0 & 0.00 \\
$50 \leq \mathrm{RS}<60$ & 20 & 17.24 & 0 & 0.00 \\
$60 \leq \mathrm{RS}<70$ & 0 & 0.00 & 9 & 25.71 \\
$70 \leq \mathrm{RS}<80$ & 0 & 0.00 & 24 & 68.57 \\
$80 \leq \mathrm{RS}<90$ & 0 & 0.00 & 2 & 5.71 \\
Mean & 43.60 & - & 73.77 & - \\
Std & 7.61 & - & 5.23 & - \\
Maximum & 62.73 & - & 85.45 & - \\
Minimum & 22.73 & - & 63.64 & -
\end{tabular}

Authors' compilation, 2019.

of the respondents (about 49.14\%) of the communities nearer to the camp area lies between $40 \leq \mathrm{RS}<50$, whereas the satisfaction of the more significant number of respondents (about 68.57\%) of the communities away from the camp areas lies between $70 \leq \mathrm{RS}<80$. This implies that residents living nearer to the camp area are less satisfied than the residents who are living away from the camp area. The estimated results suggest that after the Rohingya influx, the satisfaction score of the communities nearer to camp areas has been reduced by around 30.17 .

\section{Relocation Intention due to Rohingya Influx}

Figure 2 demonstrates the comparison statistics of the households' intention to relocate and plans for relocation as well as the relocation decisions of their neighbours and relatives. The results are presented across both nearer and distant communities. It reveals that amongst those living closer to the camps, about $30.17 \%$ of respondents very likely and $17.24 \%$ likely intend to leave, whereas very few of the respondents from the distant communities intend to move. Meanwhile, about $30.17 \%$ of respondents living nearer to the camp areas say they are very unlikely, and $22.41 \%$ unlikely, to leave the present living place. Meanwhile, amongst the people living in distant communities, about $57.14 \%$ are very unlikely and about $40 \%$ unlikely to relocate (Fig. 2a). Nobody living far from the camp had made plans to relocate, but about $10 \%$ of those from the nearer communities reported they already had such plans.

Those living nearer to camp areas gave improvement of their quality of life as the reason for wanting to relocate. In the qualitative survey, they mentioned various aspects of residential satisfaction as their motivation, such as the wish to live without threats of crime. One respondent (shopkeeper, 38 years old from Kutupalong village) also cited wider political concerns as a motive for migration: "I may leave this place with my family shortly, as our local leader is not protecting our demands. 


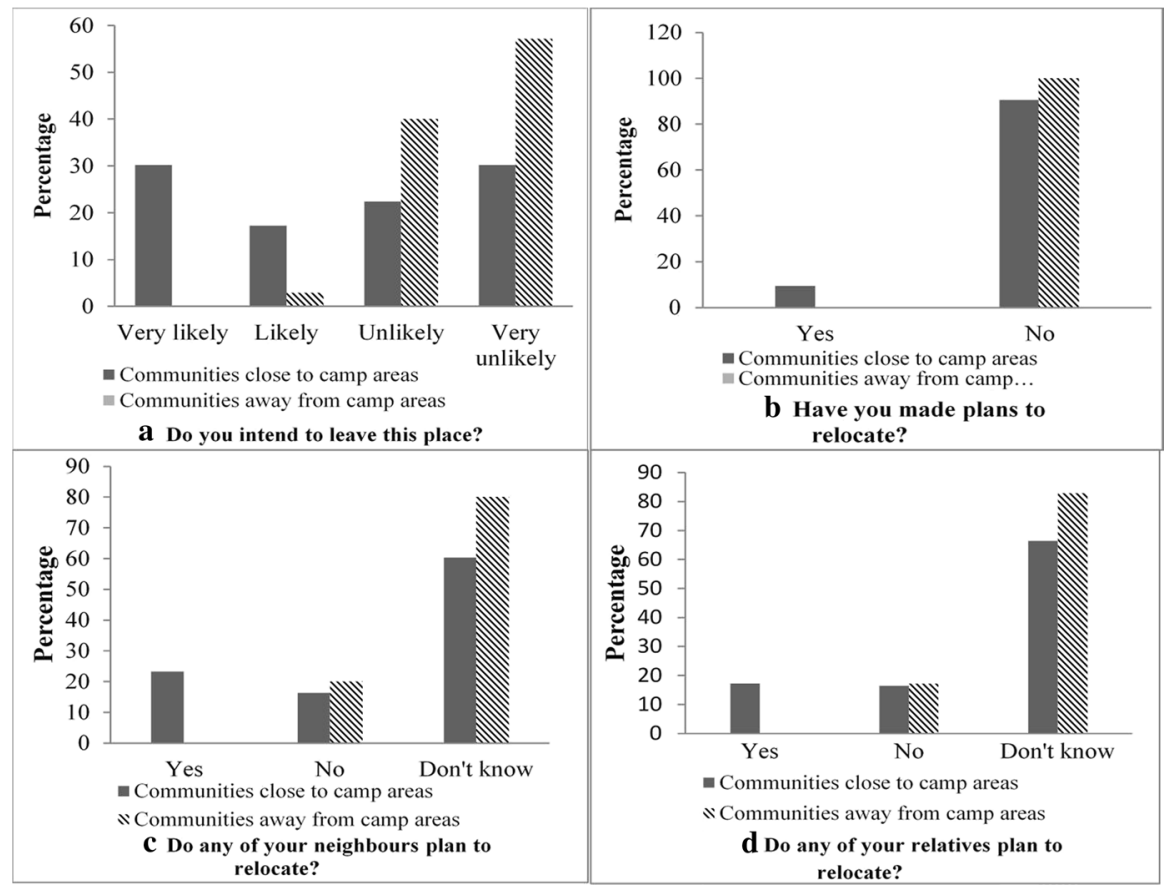

Fig. 2 Relocation intention after Rohingya influx. Source: Authors' compilation, 2019

Rather they are focusing on Rohingya issues, as they gain more monetary benefits keeping the Rohingya in Kutupalong." Meanwhile, Ukhiya residents unwilling to migrate largely cited place attachment and identity as their reason to stay, despite the socio-economic challenges they faced. "I have never thought to spend a single night outside of this place. This place means a lot to me, and it represents myself. There are lots of places in this country for a better income, but no other place can give me eternal satisfaction," said one man (carpenter, 64 years old from Kutupalong village) whose family had been living in the area for seven generations. He added, "We are a community speaking the same language, we can share our emotions, and all the people here know each other very well. I feel secure and relaxed in this place. Whatever happens to this place we can face it together, but I never think to leave this place because it completes us."

Furthermore, about $23.3 \%$ of respondents in nearer communities said that they knew of neighbours who intended to relocate, while $17 \%$ said their neighbours don't plan to relocate, and $60.34 \%$ said they have never discussed this issue with the neighbours (Fig. 2c). On the contrary, respondents in distant communities did not generally mention any of their neighbours' relocation intentions, rather, $80 \%$ said they don't know about this issue. For the case of their relatives' intention to relocate, the results were very similar: only $17.24 \%$ of the respondents living nearer to the camp area stated that their relatives plan to relocate, and $66.38 \%$ said they have no information regarding this issue (Fig. 2d). The following section shows which factors underlie the desire to relocate. 


\section{Factors that Influence the Intention of Relocation}

An ordinal logistic regression model has been employed to obtain the predictors that impact on the residents' intention to relocate. The logistic regression model was run five times to see the impact of individual components as well as to reduce the severity of multicollinearity. The results are presented in Table 7.

Model 1 of Table 7 reveals that the socio-demographic variables such as gender and household size are significant at the $10 \%$ level, and residential mobility is significant at the $1 \%$ level. This indicates that, if the household head is a male, there is a 0.69 increase in the log odd of a higher intention to move, given that other variables are held constant.

With the increase of household size, there will be a 0.23 increase in the logodds of the level of propensity to leave the place, keeping other things constant. Those aged 75 or over have a lower intention to leave compared to the reference group. The younger residents have a greater intent to move compared to the older ones, and this finding is consistent with the previous studies (Kim et al., 2015; $\mathrm{Wu}, 2006)$. The qualitative data also reinforces this generational variation. One respondent (farmer, 45 years old from Balukhali village) explained, "I cannot think to leave this place because this is my forefather's place, but my son had to leave to earn more money for our family, and also for his future." Similarly, the coefficient of residential mobility experience indicates a 2.72 increase in log odds of having a greater intention to relocate for residents who have mobility experience. The households with more children in the family do not intend as much to relocate from their present living place. The negative coefficient of the composite variable residential satisfaction $\left(S I_{r}\right)$, indicates that a lower residential satisfaction increases the mobility intention, which is also significant at $1 \%$ level.

Likewise, model 1, the model 2 of Table 7 show that the variables of gender, family size, number of children, and residential mobility experiences significant impact on the propensity to relocate. In these models, it is found that residential satisfaction is related to the social environment, and if the social environment is better the respondents prefer to stay. This indicates that the households dissatisfied with the social environment have a higher intention to move from their current living place. The coefficient of this variable is statistically significant at the $1 \%$ level. Similarly, model 3 supports the previous model 2. According to model 3 , the coefficient of the neighbourhood environment component is negatively significant at the $1 \%$ level. This indicates that respondents who are less satisfied in the neighbourhood environment also have a higher intention to leave the current place.

Model 4 of Table 7 shows that compared to the Hindu respondents, the Muslim and Buddhist respondents are not as likely to want to relocate. The coefficient for the Muslim respondents is negatively significant at the $1 \%$ level and reveals that the Muslim responders are averse to giving up their present living place. The negative coefficient for satisfaction with public services and facilities is significant at the 5\% level. This indicates that lower satisfaction with public services and facilities correlates to a higher intention to migrate, but this component is not as influential as the social environment and neighbourhood environment. 


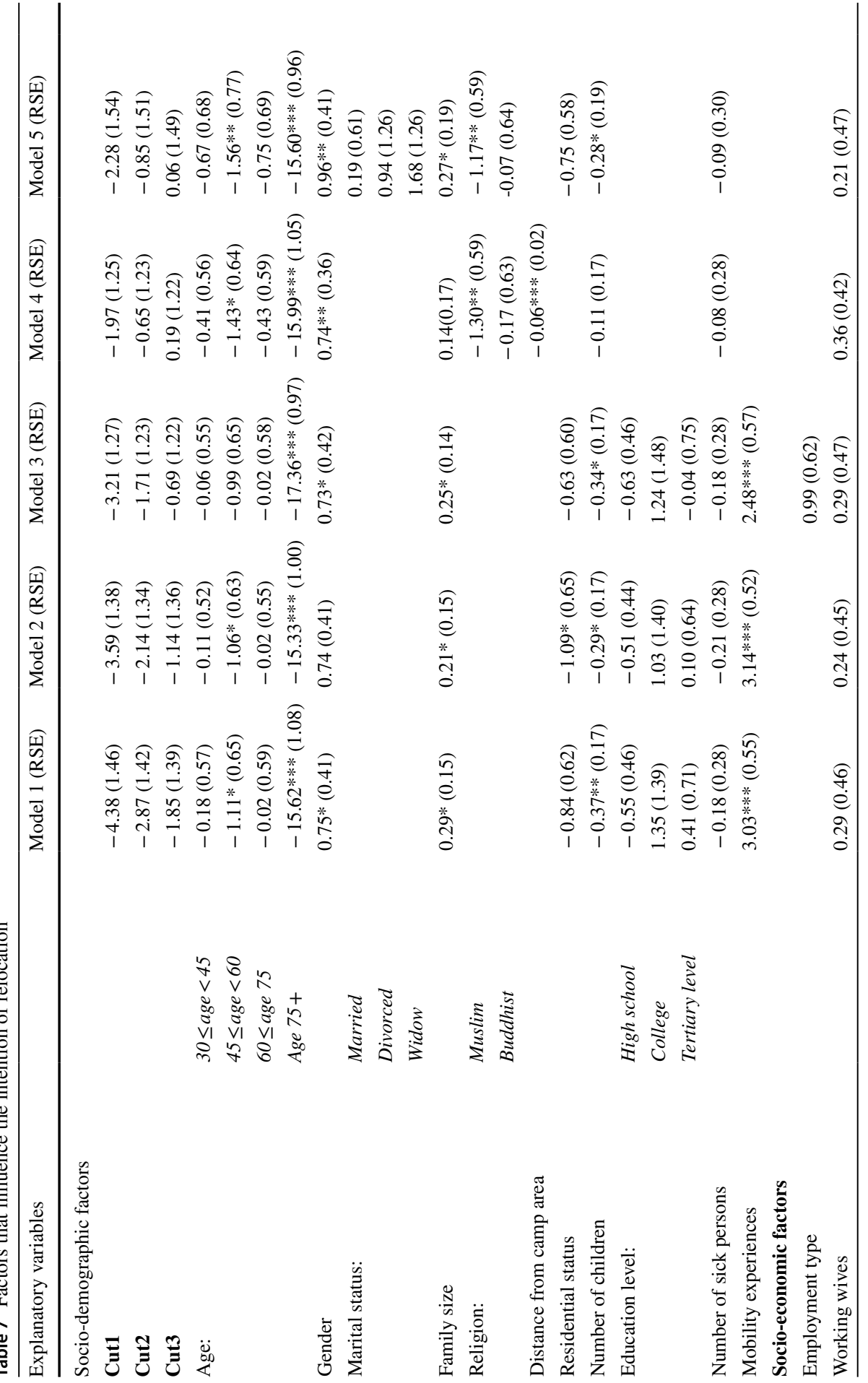




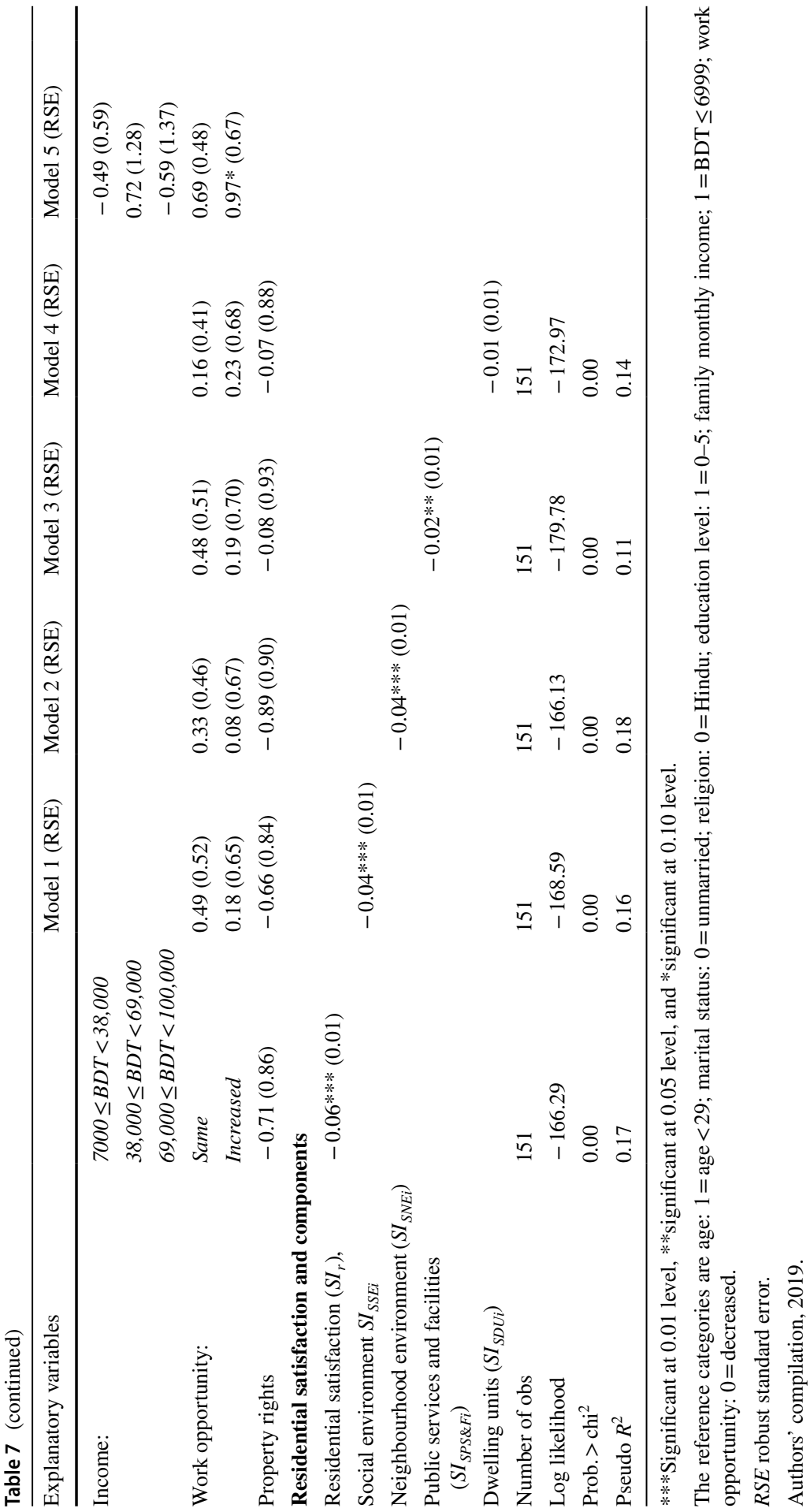


Finally, model 5 shows that there is no significant relationship between the dwelling unit component and intention to relocate. Again, in this model, gender and family size are positively and length of residence, number of children, and the categorical variable Muslim are negatively correlated with the propensity to leave. Furthermore, like the previous models, this indicates that the older age group (75 or over) has a lower intention to move. Conversely, the negative coefficient of the location variable indicates that households living closer to the camp area have a greater intention to leave their current living place. The respondents whose employment opportunities have increased or remained the same following the influx of Rohingya have a higher intention to relocate than those whose opportunities have been reduced. This suggests that if they had enough money to move to other places, they might leave their current residence.

\section{Discussion}

The influx of Rohingya refugees has a significant influence on the dissatisfaction of the Bangladeshi people living near the camp area, acting as a push factor for the propensity to move. Using a series of indicators drawn from previous studies on residential satisfaction, this study shows that the mean residential satisfaction scores of the communities closer and more distant to the Rohingya camps are 43.6 and 73.77 , respectively. This finding suggests that in the aftermath of the Rohingya influx, the overall residential satisfaction level of the host community close to the camp has declined by 30.17 . The results from the ranking of the satisfaction levels and mean comparison reveal that these residents are less satisfied with the social environment, neighbourhood environment, and public services and facilities as compared to the dwelling unit component. Particularly, these results show that people living near camp area are especially less satisfied with the public transportation system, access to recreation, greenery, pollution, crowdedness, density of housing, and safety from social crime.

The results from the ordered logistic model postulate that the socio-demographic variables of gender, household size, and mobility experience positively, and distance of households from the camp area, length of residence, and number of children negatively and significantly impact on the propensity to relocation. Here, the residents living nearer to the camp area strongly intend to leave the place. Hindu residents have a higher propensity to relocate from their current living place compared to those who are Muslim or Buddhist. Again, there is a higher intention to relocate amongst people whose monthly income has increased compared to those whose monthly income has declined. The regression analysis also demonstrates that the residential satisfaction components of satisfaction with the social environment, neighbourhood environment, and public services and facilities negatively and significantly impact on the intention to move. Overall, the analysis finds that due to the influx of Rohingya, a portion of the population may leave their current living place.

With regard to previous studies on residential satisfaction, the findings uphold that social environment, neighbourhood quality, and public services and facilities are all important contributors to people's residential satisfaction (Biswas et al., 
2021). The relationship demonstrated between changing residential satisfaction and desire to relocate likewise affirms that, for the Bangladeshi host community, residential satisfaction functions as an intervening variable between residential attributes and mobility intentions (Speare, 1974). However, the positive correlation between income and intention to relocate reinforces that other variables than satisfaction, like the logistics of relocation, also modify mobility intentions (Mudege and Zulu, 2010). Additionally, the qualitative reflections demonstrate the affective impacts of migration on the host community, including the feelings of loss and tension in their local social fabric. The study contributes to the literature on this theme by illuminating how migration affects residential satisfaction and housing mobility for the host community.

Again, 'co-existence' between host communities and Rohingya people is also an important aspect of residential satisfaction in this area (Jerin \& Mozumder, 2019), which has slowly developed in the communities neighbouring the camps. However, we observed that the negative sentiment within the host community towards the Rohingya refugees was growing for diverse reasons. One of the main reasons was that they were losing their livelihoods due to competition from the Rohingya people for available resources. For example, the Rohingya had grabbed most of the agricultural land for their homesteads. They regularly came to the host community's nearest forest to collect fuelwood, creating further tension between them. As aid and health facilities focus on the displaced Rohingya, the host communities feel excluded because they too have been facing a lack of health professionals, caregivers, medicines, and vaccines. Furthermore, access to regular education is mentioned as a primary concern of the host community, as after the Rohingya influx, teachers have quit from local primary schools and joined the 'Learning Center (LC) program' for Rohingya children in the camp, which offers a higher salary. Thus, local children have been facing problems in their schools (Ahmad \& Naeem, 2020). Competition for resources therefore hinders their peaceful co-existence. Future research may investigate quality of social co-existence more deeply, as it was out of the largely economic scope of our study.

Overall, residential satisfaction of host communities may be an important dimension of forced migration scenarios as it is likely to impact the long-term cohesion and make-up of the households, particularly by influencing relocation decisions. The following indicators, in particular, have valuable implications for future approaches to host communities, both in Bangladesh and further afield. A key finding of the study is that the distance from the camps plays a key role in residential satisfaction. This is a novel finding that indicates that establishing refugee camps farther away from the nearby host communities may reduce the relocation intentions of people from these communities and help maintain their residential satisfaction. Satisfaction with pollution levels and the greenery scenario are seen to be amongst the variables most affected by the Rohingya exodus. This provides support to calls for improved environmental management in response to the ecological effects of the population influx, which emphasise the importance of sustainable resource mobilisation for locals, migrants, and environment alike (Hassan et al., 2018). The decreased satisfaction with the neighbourhood environment and public services and facilities, including Union Parishad services, also suggests that greater local level action to 
support host communities could be facilitated to help ensure the community member's quality of life. Overall, the impact on host communities' residential satisfaction revealed by this study indicates that government and NGO programmes alike should seek to better account for the perspectives of the host community when formulating comprehensive responses to the Rohingya refugee crisis, and other such crises. Finally, the key variables shown to be affected by the Rohingya influx may be considered for future assessments of residential satisfaction in the course of building refugee camps. The outcomes of this study can support government, non-government, and different humanitarian agencies in producing proper policies and programmes to aid host communities.

Acknowledgements The authors are highly indebted to Babul Shaikh (Sraban) for his hard work during the field survey. All the authors acknowledge the cordial support from the respondents in the study villages, without whom it would have been impossible to complete the field data collection. Authors are grateful to Jochen Schanze for his insightful recommendations during the preparation of the manuscript.

Funding Open Access funding enabled and organized by Projekt DEAL. BM received the support of EU Horizon 2020 MSCA Award number: 846129 - HoMe - H2020-MSCA-IF-2018 and Technische Universität Dresden, Germany Award Number F-003661-553-Ü1G-1212042.

Open Access This article is licensed under a Creative Commons Attribution 4.0 International License, which permits use, sharing, adaptation, distribution and reproduction in any medium or format, as long as you give appropriate credit to the original author(s) and the source, provide a link to the Creative Commons licence, and indicate if changes were made. The images or other third party material in this article are included in the article's Creative Commons licence, unless indicated otherwise in a credit line to the material. If material is not included in the article's Creative Commons licence and your intended use is not permitted by statutory regulation or exceeds the permitted use, you will need to obtain permission directly from the copyright holder. To view a copy of this licence, visit http://creativecommons.org/licen ses/by/4.0/.

\section{References}

Adams, H., \& Kay, S. (2019). Migration as a human affair: Integrating individual stress thresholds into quantitative models of climate migration. Environmental Science \& Policy, 93, 129-138.

Ahmad, S. M., \& Naeem, N. (2020). Adverse economic impact by Rohingya refugees on Bangladesh: Some way forwards. International Journal of Social, Political and Economic Research, 7(1), 1-14. https://doi.org/10.46291/IJOSPERvol7iss1pp1-14

Ali, J. A., Imana, D. K., \& Ocha, W. (2017). The refugee crisis in Kenya: Exploring refugee-host community causes of tensions and conflicts in Kakuma refugee camp. J Int Relat Foreign Policy, 5(2), 39-51. https://doi.org/10.15640/jirfp.v5n2a4

Amerigo, M. (1992). A model of residential satisfaction. Socio-Environmental Metamorphoses: Builtscape, landscape, ethnoscape, euroscape, 5.

Amérigo, M., \& Aragonés, J. I. (1990). Residential satisfaction in council housing. Journal of Environmental Psychology, 10(4), 313-325.

Amérigo, M., \& Aragones, J. I. (1997). A theoretical and methodological approach to the study of residential satisfaction. Journal of Environmental Psychology, 17(1), 47-57.

Amole, D. (2009). Residential satisfaction in students' housing. Journal of Environmental Psychology, 29(1), 76-85.

Aulia, D. N., \& Ismail, A. M. (2013). Residential satisfaction of middle income population: Medan city. Procedia-Social and Behavioral Sciences, 105, 674-683.

Bach, R. L., \& Smith, J. (1977). Community satisfaction, expectations of moving, and migration. Demography, 14(2), 147-167. 
Bangladesh Bureau of Statistics. (2011). Report of the household income and expenditure survey 2010. Bangladesh Bureau of Statistics.

Bangladesh Network (2015). "Details of Cox's Bazar District" [Online]. Available: https://www.theba ngladesh.net/coxs-bazar-details.html [Online accessed on 02 September2019 at 11:00 AM]

Banglapedia (2015). "Ukhiya Upazila" [Online]. Available: http://en.banglapedia.org/index.php?title= Ukhia_Upazila [Online accessed on 02 September 2019 at 10:00 AM]

Barcus, H. (2004). Urban-rural migration in the USA: An analysis of residential satisfaction. Regional Studies, 38(6), 643-657.

Biswas B, Ahsan MN, Mallick B. (2021) Analysis of residential satisfaction: An empirical evidence from neighbouring communities of Rohingya camps in Cox's Bazar, Bangladesh. Plos one.16(4):e0250838. https://doi.org/10.1371/journal.pone.0250838.

Buys, L., \& Miller, E. (2012). Residential satisfaction in inner urban higher-density Brisbane, Australia: Role of dwelling design, neighbourhood and neighbours. Journal of Environmental Planning and Management, 55(3), 319-338.

Byun, G., \& Ha, M. (2016). The factors influencing residential satisfaction by public rental housing type. Journal of Asian Architecture and Building Engineering, 15(3), 535-542.

Carvalho, M., George, R. V., \& Anthony, K. H. (1997). Residential satisfaction in Condominios Exclusivos (Gate-Guarded Neighborhoods) in Brazil. Environment and Behavior, 29(6), 734-768.

Cutter, S. (1982). Residential satisfaction and the suburban homeowner. Urban Geography, 3(4), $315-327$.

Day, J. (2013). Effects of involuntary residential relocation on household satisfaction in Shanghai China. Urban Policy and Research, 31(1), 93-117.

Deane, G. D. (1990). Mobility and adjustments: Paths to the resolution of residential stress. Demography, 27(1), 65-79.

Dekker, K., De Vos, S., Musterd, S., \& Van Kempen, R. (2011). Residential satisfaction in housing estates in European cities: A multi-level research approach. Housing Studies, 26(04), 479-499.

Dey, S. (2018). Adverse Rohingya impacts on Bangladeshi economy and its solutions. American Journal of Trade and Policy, 5(2), 81-84. https://doi.org/10.18034/ajtp.v5i2.438

Fang, Y. (2006). Residential satisfaction, moving intention and moving behaviours: A study of redeveloped neighbourhoods in inner-city Beijing. Housing Studies, 21(5), 671-694.

Gan, X., Zuo, J., Wen, T., \& She, Y. (2019). Exploring the adequacy of massive constructed public housing in China. Sustainability, 11(7), 1949.

Gengo, R. G., Oka, R. C., Vemuru, V., Golitko, M., \& Gettler, L. T. (2018). Positive effects of refugee presence on host community nutritional status in Turkana County Kenya. American Journal of Human Biology, 30(1), e23060. https://doi.org/10.1002/ajhb.23060

GFDRR (Global Facility for Disaster Reduction and Recovery). (2018). Rohingya crisis 2017-2018 draft rapid impact, vulnerability and needs assessment: Executive summary. Available at: https://www. gfdrr.org/sites/default/fles/Rohingya $\% 2520$ crisis $\% 2520$ exec $\% 2520$ summary-2.pdf

Guillen-Royo, M., Camfield, L., \& Velazco, J. (2013). Universal and local reconciled: Exploring satisfaction with universal and local goals in Thailand and Bangladesh. Social indicators research, 113(2), 627-645. Habitat International, 49, 497-507.

Hassan, M. M., Smith, A. C., Walker, K., Rahman, M. K., \& Southworth, J. (2018). Rohingya refugee crisis and forest cover change in Teknaf Bangladesh. Remote Sensing, 10(5), 689.

HDX (2019). The Humanitarian Data Exchange [Online]. Available: https://data.humdata.org/ [Online accessed on 5 September 2019 at 10:00 AM]

Hourihan, K. (1984). Context-dependent models of residential satisfaction: An analysis of housing groups in Cork Ireland. Environment and Behavior, 16(3), 369-393.

Humanitarian Exchange (2018). Rohingya refugees in Bangladesh: The humanitarian response. Humanitarian practice network.

Hur, M., \& Morrow-Jones, H. (2008). Factors that influence residents' satisfaction with neighborhoods. Environment and Behavior, 40(5), 619-635.

ISCG (2018). Support to Bangladesh Host Communities and Institutions in the Joint Response Plan for the Rohingya Humanitarian Crisis

ISCG (2018). Support to Bangladesh Host Communities and Institutions in the Rohingya Refugee Response Joint Response Plan'.

Jerin, M. I., \& Mozumder, M. K. (2019). Exploring host community attitudes towards Rohingya refugees in Bangladesh. Intervention, 17, 169-173. https://doi.org/10.4103/INTV.INTV_27_19 
Jiang, W., Feng, T., Timmermans, H., \& Li, H. (2017). A gap-theoretical path model of residential satisfaction and intention to move house applied to renovated historical blocks in two Chinese cities. Cities, 71, 19-29.

Kim, H., Woosnam, K. M., Marcouiller, D. W., \& Aleshinloye, K. D. (2015). Residential mobility, urban preference, and human settlement: A South Korean case study.

Kumssa, A., \& Jones, J. F. (2014). Human security issues of Somali Refugees and the host community in Northeastern Kenya. Journal of Immigrant \& Refugee Studies, 12(1), 27-46. https://doi.org/10. 1080/15562948.2013.810797

Li, S., \& Song, Y. (2009). Redevelopment, displacement, housing conditions, and residential satisfaction: A study of Shanghai. Environment and Planning a: Economy and Space, 41(5), 1090-1108. https:// doi.org/10.1068/a4168

Li, S. (2004). Life course and residential mobility in Beijing China. Environment and Planning A, 36(1), 27-43.

Li, Z., \& Wu, F. (2013). Residential satisfaction in China's informal settlements: A case study of Beijing Shanghai, and Guangzhou. Urban Geography, 34(7), 923-949.

Liao, P. S. (2004). Emotional attachment, residential satisfaction, and mobility propensity. In Journal of Population Study.

Lu, M. (1999). Determinants of residential satisfaction: Ordered logit vs. regression models. Growth and Change, $30,264 \mathrm{e} 287$.

Mackreath, H. (2014). The role of host communities in north Lebanon. Forced Migration Review, 47, 19-21.

Martin, A. (2005). Environmental conflict between refugee and host communities. Journal of Peace Research, 42(3), 329-346.

Maystadt, J. F., Hirvonen, K., Mabiso, A., \& Vandercasteelen, J. (2019). Impacts of Hosting Forced Migrants in Poor Countries. Annual Review of Resource Economics, 11(1), 439-459. https://doi.org/ 10.1146/annurev-resource-090518-095629

Mesch, G. S., \& Manor, O. (1998). Social ties, environmental perception, and local attachment. Environment and Behavior, 30(4), 504-519.

Mohit, M. A., Ibrahim, M., \& Rashid, Y. R. (2010). Assessment of residential satisfaction in newly designed public low-cost housing in Kuala Lumpur Malaysia. Habitat International, 34(1), 18-27.

Mridha, A. M. M. H., \& Moore, G. T. (2011). The quality of life in Dhaka. Neighborhood quality as a major component of residential satisfaction. In Investigating.

Mridha, M. (2020). The effect of age, gender and marital status on residential satisfaction. Local Environment, 25(8), 540-558.

Mudege, N. N., \& Zulu, E. M. (2011). In their own words: Assessment of satisfaction with residential location among migrants in Nairobi slums. Journal of Urban Health, 88(2), 219-234.

Riley, A., Varner, A., Ventevogel, P., Taimur Hasan, M. M., \& Welton-Mitchell, C. (2017). Daily stressors, trauma exposure, and mental health among stateless Rohingya refugees in Bangladesh. Transcultural Psychiatry, 54(3), 304-331.

Rioux, L., \& Werner, C. (2011). Residential satisfaction among aging people living in place. Journal of Environmental Psychology, 31(2), 158-169.

Rojo-Perez, F., Fernandez-Mayoralas Fernandez, G., \& Pozo Rivera, E. (2001). Ageing in place: Predictors of the residential satisfaction of elderly. Social Indicators Research, 54, 173-208.

Speare, A., Jr., Kobrin, F., \& Kingkade, W. (1982). The influence of socioeconomic bonds and satisfaction on interstate migration. Social Forces, 61(2), 551-574.

Speare, J. A. (1974). Residential satisfaction as an intervening variable in residential mobility. Demography, 11(2), 173-188.

Tao, L., Hui, E. C., Wong, F. K., \& Chen, T. (2015). Housing choices of migrant workers in China: Beyond the Hukou perspective. Habitat International, 49, 474-483.

Tao, L., Wong, F. K., \& Hui, E. C. (2014). Residential satisfaction of migrant workers in China: A case study of Shenzhen. Habitat International, 42, 193-202.

Ullah, S. M. A., Asahiro, K., Moriyama, M., \& Tani, M. (2021). Socioeconomic status changes of the host communities after the Rohingya refugee influx in the Southern coastal area of Bangladesh. Sustainability, 13, 4240. https://doi.org/10.3390/su13084240

UNDP and UN Women (2017). 'Rohingya refugee crisis in Bangladesh: Rapid early recovery assessment of host community impacts. United Nation Entity for Gender Equality and the Empowerment of Women. 
Verme, P., \& Schuettler, K. (2021). The impact of forced displacement on host communities a review of the empirical literature in economics. Journal of Development Economics, 102606. https://doi.org/ 10.1016/j.jdeveco.2020.102606

Weidemann, S., \& Anderson, J. R. (1985). A conceptual framework for residential satisfaction. In Home environments (pp. 153-182). Springer, Boston, MA.

Wu, W. (2006). Migrant intra-urban residential mobility in urban China. Housing Studies, 21(5), $745-765$.

Publisher's Note Springer Nature remains neutral with regard to jurisdictional claims in published maps and institutional affiliations.

\section{Authors and Affiliations}

\section{Bangkim Biswas $^{1} \cdot$ Bishawjit Mallick $^{2}$ D $\cdot$ Nasif Ahsan $^{3} \cdot$ Rupkatha Priodarshini $^{4}$}

Bangkim Biswas

bangkimbiswas@gmail.com

Nasif Ahsan

nasif.ahsan@econ.ku.ac.bd

Rupkatha Priodarshini

rup.priodarshini@yahoo.co.uk

1 Coastal Research Foundation (CRF), Khulna 9250, Bangladesh

2 Chair of Environmental Development and Risk Management, Faculty of Environmental Sciences, Technische Universität Dresden, Dresden, Germany

3 Economics Discipline, Khulna University, Khulna 9208, Bangladesh

4 International Center for Climate Change Adaptation and Development (ICCCAD), Dhaka, Bangladesh 